\title{
グローカル化する地域のソーシャルワークとリハビリテーション The Social Work and Community Based Rehabilitation at Glocalized Society
}

\author{
企画者・司会者山田 健司（帝京科学大学）

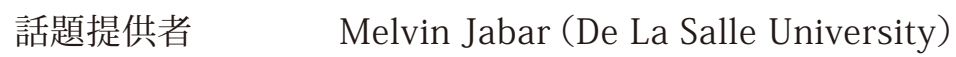 \\ Johanna Zulueta (Soka University) \\ Dorothy Dimaandal (Davao Regional Medical Center)
}

概要

前例のない程の人口減少と高齢化が、日本社会で加速しています。そして日本を世界中が見つめている、 何が起こりつつあるのかと。国家のアイデンティティが、経済、人、物、情報そして環境などほぼすべての 分野が一体化するなかで、「グローバル」に包摂されつつあるようもみえます。この現象の究極点は、わたし たちの生活が展開する場所、すなわち「地域=ローカル」です。これが「グローカル」の所以なのでしょう。

このシンポジウムでは、世界トップスピードの「人口減少高齢化社会」と「グローカル」の掛け算を試み ます。具体には、個々の地域の特性や環境を基盤に展開するリハビリ(医療、リハ、福祉、介護等の一体化)、 高齢化する日本在住外国人、グローカル社会におけるソーシャルワーク、の視点からアジア気鋭の若手研究 者たちが、掛け算を展開します。正解は出せないでしょうが、いま直面している大課題を少しでも前向きに 正視する、という試みでもあるのです。 